\title{
Isolasi dan Identifikasi Aeromonas spp. dari Lele Dumbo (Clarias sp.) Sakit di Kabupaten Ngawi
}

\author{
Isolation and Identification of Aeromonas spp. \\ from Diseased African Catfish (Clarias sp.) in Ngawi Regency
}

\author{
Sri Rejeki, Triyanto \& Murwantoko*
}

Departemen Perikanan, Fakultas Pertanian UGM

Jl. Flora Gd A4 Bulaksumur, Yogyakarta 55281

Penulis untuk korespondensi, e-mail: murwantoko@ugm.ac.id

\begin{abstract}
Abstrak
Lele dumbo (Clarias sp.) merupakan satu jenis ikan air tawar penting yang digemari oleh masyarakat karena memiliki banyak kelebihan. Bakteri Aeromonas sp. merupakan penyakit berbahaya pada budidaya air tawar. Penelitian ini bertujuan untuk mengisolasi, mengidentifikasi dan mengetahui patogenisitas bakteri Aeromonas sp. dari lele dumbo Kabupaten Ngawi. Sampel ikan lele berukuran 20 - $25 \mathrm{~cm}$ yang menunjukkan gejala sakit diperoleh dari kolam pembesaran di 3 kecamatan. Bakteri diisisolasi dari ginjal diinokulasikan pada medium GSP. Karakterisasi dan identifikasi bakteri melalui pengamatan morfologi koloni, sel, dan sifat biokimia. Pembuktian sifat patogen dengan uji Postulat Koch. Tingkat patogensitas dianalisis dengan mengukur nilai Lethal Dosage 50 pada benih lele ukuran $7-9 \mathrm{~cm}$. Hasil pengamatan menunjukkan gejala penyakit pada ikan yang terserang bakteri berupa luka borok pada kulit, pembengkakan pada bagian perut dan kerusakan ginjal. Isolasi bakteri yang diperoleh berjumlah 15 yang terdiri dari lima, enam dan empat isolat yang masing masing berasal dari Kecamatan Karang Jati, Geneng dan Paron. Hasil identifikasi menunjukkan bahwa 12 isolat (GKJ1, GKJ3, GKJ4, GGN1, GGN2, GGN3, GGN4, GGN5, GGN6, GPR2, GPR3 dan GPR4 teridentifikasi sebagai bakteri Aeromonas hydrophila. Tiga isolat (GKJ2, GKJ5 dan GPR1) teridentifikasi sebagai bakteri $A$. salmonicida. Isolat A. hydrophila GKJ1, GKJ4, GGN2, GGN5, GPR2 dan GPR4 bersifat virulen terhadap lele dumbo dengan LD $_{50}$ $1,55 \times 10^{5}, 3,89 \times 10^{5}, 7,24 \times 10^{5}, 2,39 \times 10^{5}, 6,61 \times 10^{4}$ dan $1,95 \times 10^{4} \mathrm{cfu} / \mathrm{ikan}$.
\end{abstract}

Kata kunci: Aeromonas, identifikasi, lele dumbo, patogenisitas

\begin{abstract}
African catfish (Clarias sp) is one of important freshwater fish which prefer consumed by people due to many advantages. Aeromonas sp. bacteria are dangerous patogen for freshwater fishes. This objective of the research was to isolate, identify and determine pathogenicity of Aeromonas sp. bacteria from African catfish from District Ngawi. The samples of catfish with $20-25 \mathrm{~cm}$ length showing clinical signs disease were obtained from three sub districts. Bacteria were isolated from kidney and inoculated into GSP medium. Characterization and identification through morphology of bacterial colonies, cells and biochemical test. Postulate Koch was conducted to verify abaility to couse disease. Pathogenicity was analyzed by determination of value of Lethal Dosage- 50 on catfish on $7-9 \mathrm{~cm}$ length. The result showed that the disease symptoms of fish infected by the bacteria were skin ulcer, abdominal swelling and kidney damage. Fifteen bacterial isolates were collected which five, six and four isolates were from Kecamatan Karang Jati, Geneng dan Paron.sub-district respectively. The result showed 12 isolates (GKJ1, GKJ3, GKJ4, GGN1, GGN2, GGN3, GGN4, GGN5, GGN6, GPR2, GPR3 and GPR4) were identified as Aeromonas hydrophila. Three isolates (GKJ2, GKJ5 and GPR1) were identified as A. salmonicida. Isolate of $A$. hydrophila GKJ1, GKJ4, GGN2, GGN5, GPR2 and GPR4 were virulent to African catfish with $\mathrm{LD}_{50}$ values of $1,55 \times 10^{5}, 3,89 \times 10^{5}, 7,24 \times 10^{5}, 2,39 \times 10^{5}, 6,61 \times 10^{4}$ and $1,95 \times 10^{4} \mathrm{cfu} / \mathrm{fish}$.
\end{abstract}

\section{Keywords: Aeromond, African catfish, identification, pathogenicity}

\section{Pengantar}

Lele dumbo adalah salah satu jenis ikan air tawar yang digemari oleh masyarakat dan mempunyai nilai gizi yang baik. Santoso (1994) menyatakan lele dumbo sangat toleran terhadap suhu air yang cukup tinggi, yaitu pada kisaran $25-32{ }^{\circ} \mathrm{C}$. Lele dumbo memiliki alat pernafasan tambahan berupa arborescent yang merupakan kulit tipis, menyerupai spon yang berfungsi membantu mengambil oksigen bebas di udara. Menurut Irianto (2004), salah satu permasalahan budidaya ikan air tawar yang dihadapi sekarang adalah terjadinya serangan penyakit 
bakterial.

Aeromonas merupakan bakteri yang berasal dari lingkungan perairan dan dapat menyebabkan berbagai penyakit pada ikan. Menurut Holt et al. (1994), genus Aeromonas memiliki sifat Gram negatif, oksidasi positif, katalase positif dan bersifat fermentative. Bakteri ini juga mampu memfermentasikan beberapa gula seperti glukosa, fruktosa, maltosa, dan trehalosa. Wakabongo (1992), menyatakan identifikasi Aeromonas hingga level genus dapat dilakukan dengan melakukan isolasi bakteri pada medium selektif dan identifikasi Aeromonas hingga level spesies dapat dilakukan dengan mengetahui karakteristik fenotip yang meliputi produksi gas dari fermentasi glukosa, produksi asam dari mannitol dan arabinose, lisin dekarboksilase, ornithin dekarboksilase serta arginin dehydrolase.

A. hydrophila telah diidentifikasi sebagai patogen dari berbagai jenis ikan air tawar, penyebab penyakit Motile Aeromonas septisemia (MAS) di seluruh dunia. MAS ini ditandai oleh adanya lesi kecil permukaan (yang mengarah pada lepasnya sisik), pendarahan lokal terutama insang dan anus, bisul, abses, exophthalmia dan perut kembung. Secara internal, mungkin ada akumulasi cairan asites, dan kerusakan pada organ-organ, terutama ginjal dan hati (Austin \& Austin, 2007). Irianto (2004), menambahkan secara histopatologis tampak terjadinya nekrosis pada limpa, hati, ginjal dan jantung. Isolat $A$. hydrophila dinyatakan virulen apabila memiliki LD $_{50}$ berkisar antara $10^{4}-10^{6} \mathrm{cfu} / \mathrm{ml}$ (Nitimulyo, 1993). Menurut Stevenson (1988), Isolat $A$. hydrophila dengan $L_{50}$ $10^{4}-10^{5} \mathrm{cfu} / \mathrm{ml}$ digolongkan sebagai isolat yang bersifat virulen, sedangkan isolat yang memiliki $L_{50}$ $10^{7} \mathrm{cfu} / \mathrm{ml}$ atau lebih dinyatakan non virulen.

Aeromonas salmonicida merupakan penyebab penyakit furunculosis yang awalnya dianggap hanya menginfeksi salmonids, tapi dalam perkembangannya patogen ini telah menginfeksi berbagai famili Cyprinidae, Serranidae dan Anoplopomatidiae (Austin \& Austin, 2007). Serangan furunculosis dapat digolongkan dalam beberapa bentuk diantaranya bentuk sub-akut atau kronis biasa ditemui pada ikan dewasa yang ditandai aktifitas berenang menurun, berenang tidak menentu, gerakan lamban, berhenti makan, sirip geripis dan pendarahan pada insang (Noga, 2000). Dalam beberapa ikan, terutama non-salmonids, penyakit ini bisa muncul dalam bentuk ulseratif dermatitis, ulserasi dan internal dapat ditemui kerusakan pada hati dan ginjal serta pembengkakan pada limpa. Furunculosis sub-akut hanya menyebabkan kematian yang rendah dan masih dapat bertahan hidup Furunculosis akut biasanya muncul tiba-tiba, terjadi dalam waktu singkat dan biasanya ikan mati dalam waktu 2 - 3 hari (Noga, 2000, Austin \& Austin, 2007).

Budidaya lele dumbo Dengan berkembangnya di berbagai daerah. Sementara itu penyakit ikan juga dapat menyebar, maka penelitia ini bertujuam :untuk mengisolasi Aeromonas sp. penyebab penyakit pada lele dumbo (Clarias sp.) dari Kabupaten Ngawi dan mengetahui patogenisitasnya.

\section{Metode Penelitian}

Pengambilan Sampel

Pengambilan sampel dilakukan secara acak melalui penyisiran pada lokasi budidaya, yaitu kolam-kolam pemeliharaan dan pembesaran lele di tiga kecamatan yaitu Kecamatan Karang Jati, Kecamatan Geneng dan Kecamatan Paron. Pengambilan sampel dilakukan secara selektif terhadap ikan yang menunjukkan gejala serangan Aeromonas sesuai Austin \& Austin (1987). Sampel diambil berdasarkan adanya gejala berupa luka seperti borok pada kulit, luka kemerahan pada mulut, mata menonjol dan perut membengkak.

Isolasi dan Karakterisasi Bakteri

Isolasi dilakukan dengan mengambil bakteri dari bagian ginjal secara aseptis menggunakan jarum ose, kemudian diinokulasikan pada medium GSP dan diinkubasi pada suhu $30{ }^{\circ} \mathrm{C}$ selama 24 jam. Koloni-koloni bakteri yang tumbuh dimurnikan pada medium GSP. Pengamatan morfologi koloni dilakukan terhadap bakteri pada medium GSP. Morfologi koloni yang diamati meliputi warna, bentuk dan elevasi.

Karaketrisasi sel dan sifat biokimia dilakukan dengan Uji Gram dengan pengecatan dan $\mathrm{KOH}$ 3\%, Uji motility, Indol dengan Medium Motility Indole Ornithin (MIO), Uji oksidase dengan Reagen Kovacs (Oksidase): (Tetra methyl p-phenylene diamene dihidrocholoride aquosa [Merck], Uji katalase, Uji oksidatif-fermentative. Differensiasi Spesies pada Genus Aeromonas dilakukan dengan Uji hidrolisis gelatin dengan Medium gelatin (Difco), Uji produksi $\mathrm{H}_{2} \mathrm{~S}$ pada medium TSIA dengan Medium Triple Sugar Iron Agar (TSIA) (Oxoid), Uji ALO (Arginin dehydrolase, Lysin decakboksilase, Ornithin dehydrolase), Uji Methyl Red dengan Medium Methyl Red (MR) (Merck), Uji Voges-Proskauer (VP), Uji gula-gula, Uji Simmon citrate. Uji gula yang dilakukan meliputi D-glukosa [Merck], D-galaktosa [Merck], Laktosa, Maltosa, D-mannose [Difco], D-Mannitol, Raffinosa, D-sorbitol [Merck], D-xylose, Sukrosa [Merck], Threhalose, Ducitol, Glycerol). Uji sifat fisiologis dan uji sifat biokomia berdasarkan Biochemical Test for Identification of Medical Bacteria (Macfaddin, 1980),

Identifikasi Bakteria 
Karakter bakteri berdasarkan pengamatan morfologi koloni, pengujian sifat fisiologis maupun sifat biokimia disusun dalam bentuk tabel, kemudian dicocokkan dengan karakter Aeromonas sp. yang terdapat dalam buku Bergey's Manual of Determinative Bacteriology (Holt, 1994).

\section{Patogenisitas Bakteri}

Bakteri dikultur dalam medium TSB pada suhu 30 ${ }^{\circ} \mathrm{C}$ selama 24 jam. Kepadatan bakteri yang diukur dengan menggunakan spektrofotometer. Kemudian bakteri diencerkan, maka bakteri disediakan dalam tingkatan konsentrasi $2 \times 10^{4} \mathrm{cfu} / \mathrm{ml}, 2 \times 10^{6} \mathrm{cfu} / \mathrm{ml}$ dan $2 \times 10^{8} \mathrm{cfu} / \mathrm{ml}$. ikan uji yang digunakan untuk tiap perlakuan berjumlah 10 ekor. Penyuntikan bakteri dilakukan secara intramuscular pada ikan lele dumbo ukuran 7-9 cm dengan dosis masingmasing sebanyak 0,1 ml. ikan uji dipelihara dalam ember selama 14 hari dengan perlakuan aerasi dan penyiponan. Pengamatan perkembangan gejala eksternal ikan dilakukan selama 14 hari setelah infeksi. Pengamatan dilakukan secara periodik, ikan yang mengalami kematian diamati gejala internalnya. Perhitungan $\mathrm{LD}_{50}$ ditentukan dengan menggunakan metode Dragstedt-Behrens (Hubert, 1980).

\section{Hasil Dan Pembahasan}

\section{Isolasi Bakteri}

Sampel ikan lele yang diduga terserang Aeromonas sp. memiliki kisaran ukuran $20-25 \mathrm{~cm}$ yang diperoleh dari kolam-kolam pemeliharaan dan pembesaran dari tiga kecamatan di Kabupaten Ngawi yaitu Kecamatan Karang Jati, Kecamatan Geneng dan Kecamatan Paron. Semua sampel menunjukkan gejala yang hampir sama berupa luka seperti borok pada kulit, luka kemerahan pada mulut, mata menonjol dan bagian perut membengkak. Gejala internal yang terlihat berupa keluar banyak cairan ketika perut dibedah, perubahan warna pada ginjal dan kondisi ginjal yang mulai rusak. Isolasi bakteri diambil dari bagian ginjal ikan lele dan dimurnikan.

Hasil pemurnian isolasi bakteri yang didapat berjumlah 15 isolat yang terdiri dari lima isolat yang berasal dari Kecamatan Karang Jati dengan kode isolat GKJ1, GKJ2, GKJ3, GKJ4 dan GKJ5, enam isolat yang berasal dari Kecamatan Geneng dengan kode isolat GGN1, GGN2, GGN3, GGN4, GGN5 dan GGN6, serta empat isolat yang berasal dari Kecamatan Paron dengan kode isolat GPR1, GPR2, GPR3 dan GPR4. Isolat-isolat tersebut kemudian digunakan untuk uji postulat koch, patogenisitas serta uji karakterisasi dan identifikasi.

\section{Postulat Koch}

Uji postulat koch dilakukan untuk membuktikan apakah isolat bakteri yang telah diisolasi merupakan bakteri peyebab penyakit pada ikan. Pengamatan uji postulat koch dilakukan selama 14 hari meliputi pendataan mortalitas ikan uji serta pengamatan eksternal dan internall, serta melakukan reisolasi bakteri yang berasal dari dalam ginjal ikan. Hasil pengujian menunjukkan bahwa 15 isolat bakteri yang diuji dapat menyebabkan kematian ikan dengan tingkat mortalitas yang berbeda yaitu berkisar antara $40-80 \%$. Mortalitas terendah sebesar $40 \%$ terdapat pada isolat GPR1, mortalitas $50 \%$ terdapat pada isolat GKJ5, GGN1, GGN3, GGN4 dan GPR3, mortalitas $60 \%$ terdapat pada isolat GKJ2, GKJ3 dan GGN6, mortalitas $70 \%$ terdapat pada isolat GGN5, GPR2 dan GPR4, mortalitas tertinggi sebesar $80 \%$ terdapat pada isolat GKJ1, GKJ4 dan GGN2.

Gejala eksternal penyakit yang ditimbulkan dalam uji coba postulat koch secara umum hampir sama yaitu lele sering berada dipermukaan air, muncul luka seperti borok, sirip geripis, serta muncul luka kemerahan pada sekitar mulut. Gejala internal menunjukkan warna ginjal berubah menjadi lebih gelap. Bakteri yang direisolasi dari ginjal menunjukkan adanya bakteri Aeomonas. Berdasarkan hasil di atas diketahui secara umum hasil uji postulat koch sama dengan hasil karakterisasi tahap awal terhadap sampel, hal tersebut menunjukkan bahwa pendugaan isolat yang didapat merupakan penyebab penyakit bakteri adalah benar. Gejala eksternal penyakit yang ditimbulkan dalam uji coba postulat koch secara umum hampir sama dan sesuai dengan pustaka yang menyebutkan bahwa ikan yang terserang Aeromonas menunjukkan tanda-tanda seperti bercak merah pada permukaan tubuh dan sirip-sirip, mata rusak dan menonjol (Triyanto, 1991), akumulasi cairan dalam kantong perut, perut kembung, luka pada kulit, serta sisik terlepas (Capriano, 2001). Penelitian Murwantoko et al. (2013) juga menyebutkan bahwa gejala yang ditimbulkan pada uji postulat koch diantaranya sering berada dipermukaan air dengan posisi tubuh terlentang, sirip geripis, bercak merah pada rongga dan sekitar mulut, ginjal menjadi berwarna merah tua dan terjadi pembengkakan dengan tingkat mortalitas 40-100\%. Tingkat mortalitas dapat dipengaruhi oleh tingkat virulensi bakteri maupun faktor lingkungan.

\section{Differensiasi Genus Aeromonas}

Differensiasi genus dilakukan sebagai tahap awal untuk menunjukkan bahwa semua sampel isolat yang didapat termasuk dalam golongan genus Aeromonas. Semua isolat memiliki koloni berbentuk circulair, elevasi koloni berbentuk convex dan warna koloni bakteri pada medium GSP berwarna krem. Perubahan warna koloni pada medium GSP disebabkan bakteri mampu memfermentasikan karbohidrat. Sifat 
fermentative pada bakteri inilah yang membedakan genus Aeromonas dengan genus Pseudomonas pada medium GSP. Sifat fermentative bakteri juga ditunjukkan pada hasil uji O/F. Uji pengecatan Gram diperoleh hasil bakteri berwarna merah dan berbentuk batang yang menunjukkan bahwa bakteri termasuk kedalam golongan bakteri Gram negatif. Hasil uji $\mathrm{KOH}$ $3 \%$ juga menunjukkan hasil bahwa bakteri termasuk dalam golongan bakteri Gram negatif ditandai dengan terbentuknya gel. Uji katalase dan oksidase diperolah tanda positif yang menunjukkan bahwa semua bakteri mampu menghasilkan enzim katalase dan oksidase, hal tersebut sesuai dengan Holt (1994), yang menyebutkan bahwa genus Aeromonas memiliki ciri Gram negatif, katalase positif, oksidase positif dan bersifat fermentative.

\section{Differensiasi Spesies pada Genus Aeromonas}

Diferensiasi spesies pada genus Aeromonas dilakukan dengan melakukan uji biokimia terhadap 15 isolat, Adapun data hasil uji biokima dapat dilihat pada Tabel 1.

Hasil

\section{Kemiripan}

Berdasarkan tabel dapat diidentifikasi 12 isolat (80\%) termasuk dalam golongan spesies Aaeromonas hydrophila dan 3 isolat (20\%) termasuk dalam golongan spesies Aaeromonas salmonicida. Isolat yang termasuk dalam golongan spesies $A$. hydrophila diantaranya isolat dengan kode GKJ1, GKJ3, GKJ4, GGN1, GGN2, GGN3, GGN4, GGN5, GGN6, GPR2, GPR3 dan GPR4. Kisaran kesesuaian isolat terhadap bakteri $A$. hydrophila sebesar $86,67 \%-96,67 \%$. Tiga isolat (isolat GKJ2, GKJ5 dan GPR1) termasuk dalam golongan spesies $A$. salmonicida dengan kisaran kesesuaian $83,33 \%-86,67 \%$.

Tabel 1. Differensiasi spesies Aeromonas isolat bakteri dari lele dumbo.

\begin{tabular}{|c|c|c|c|c|c|c|c|c|c|c|c|c|c|c|c|}
\hline \multirow[t]{2}{*}{ Uji biokimia } & \multicolumn{5}{|c|}{ GKJ } & \multicolumn{6}{|c|}{ GGN } & \multicolumn{4}{|c|}{ GPR } \\
\hline & 1 & 2 & 3 & 4 & 5 & 1 & 2 & 3 & 4 & 5 & 6 & 1 & 2 & 3 & 4 \\
\hline MR & + & + & + & + & + & + & + & + & + & + & + & + & + & + & + \\
\hline VP & - & - & - & - & - & + & + & + & + & + & - & - & + & + & + \\
\hline Indol & + & - & + & + & - & + & - & + & + & - & - & - & + & + & + \\
\hline Motility & + & - & + & + & - & + & + & + & + & + & + & - & + & + & + \\
\hline Simmon citrate & - & + & - & - & - & + & - & + & - & - & - & - & + & + & - \\
\hline $\mathrm{H}_{2} \mathrm{~S}$ & + & - & + & + & - & + & + & + & - & + & + & - & + & + & + \\
\hline Lisin dekarboksilase & - & + & - & - & - & - & - & - & - & - & - & - & - & - & - \\
\hline Arginin dihidrolase & + & - & + & + & + & + & - & + & + & - & - & - & + & - & + \\
\hline Ornithin dekarboksilase & - & - & - & - & - & - & - & - & - & - & - & - & - & - & - \\
\hline Pemecahan gelatin & + & + & + & + & + & + & + & + & + & + & + & + & + & + & + \\
\hline D-Glucose, asam & + & + & - & + & - & + & + & + & + & + & + & + & + & - & + \\
\hline D-Glucose, gas & + & + & - & + & - & + & + & + & + & + & + & + & + & - & + \\
\hline Ducitol, asam & - & - & - & - & - & - & - & + & + & - & - & + & - & - & - \\
\hline D-Galactose, asam & + & + & + & + & + & + & + & + & - & + & + & + & + & + & + \\
\hline Glycerol, asam & + & - & + & + & - & + & + & + & + & + & + & + & + & + & + \\
\hline Lactose, asam & - & - & - & - & - & + & - & - & + & - & - & - & - & - & - \\
\hline Maltose, asam & + & - & + & - & + & + & + & + & + & + & + & + & + & + & + \\
\hline D-Mannitol, asam & + & + & + & + & - & - & + & + & + & + & + & + & - & + & - \\
\hline D-Mannose, asam & + & + & + & + & + & + & + & + & + & + & + & + & + & + & + \\
\hline Raffinose, asam & - & - & - & - & - & - & - & + & + & - & - & - & - & - & - \\
\hline D-Sorbitol, asam & - & - & - & - & - & + & - & + & - & - & - & + & - & - & - \\
\hline Sucrose, asam & + & - & + & + & + & + & + & + & + & + & + & - & + & + & + \\
\hline Trehalose, asam & + & + & + & + & - & + & + & + & + & + & + & + & + & + & + \\
\hline D-Xylose, asam & - & - & - & - & - & + & - & - & - & - & - & + & - & - & - \\
\hline
\end{tabular}


Isolat $A$. hydrophila memiliki beberapa persamaan sifat diantaranya motil, lysine dekarboksilase positif, methyl red positif, maltose positif, trehalosa positif, sucrose positif, D-mannosa positif, glycerol positif, ornithin dekarboksilase negatif, simmon sitrat positif, mampu memproduksi gelatin. Perbedaan hasil antar isolat terjadi pada uji voges proskaeur, produksi $\mathrm{H}_{2} \mathrm{~S}$, produksi indol, arginin dihydrolase dan pada semua uji gula yang dilakukan. Hasil penelitian Wakabongo (1992) menyebutkan dalam melakukan identifikasi isolat $A$. hydrophila terdapat beberapa perbedaan hasil pada uji Voges-Proskauer, lysin dekarboksilase, D-glukosa gas dan arabinosa. Perbedaan karakter juga ditunjukkan dalam penelitian Angka (1995) yang menyebutkan adanya perbedaan hasil uji lysine dekarboksilase, produksi $\mathrm{H}_{2} \mathrm{~S}$, hidrolisis eskulin, arabinosa serta sorbitol pada identifikasi beberapa isolate $A$. hydrophila. Perbedaan hasil identifikasi pada uji methyl red, sukrosa, D-xylase, D-sorbitol, D-galaktosa dan D-mannitol juga ditunjukkan dalam penelitian Murwantoko et al. (2013).

Isolat $A$. salmonicida memiliki beberapa persamaan sifat diantaranya non motil, methyl red positif, voges proskaeur negatif, produksi indol negatif, produksi $\mathrm{H}_{2} \mathrm{~S}$ negatif, ornithin dekarboksilase negatif, lactosa negatif, raffinosa negatif, D-galaktosa positif, D-mannosa positif, mampu menghasilkan gelatin. Terdapat perbedaan hasil uji pada arginin dehydrolase, lysine dekarboksilase dan pada uji gula. Adanya perbedaan tersebut merupakan sesuatu yang normal karena disamping memiliki variasi spesies, Aeromonas sp. juga memiliki variasi strain diantaranya berupa variasi sifat biokimia (Holt, 1994).

Terdapat perbedaan karakter antara spesies $A$. hydrophila dan A. salmonicida yaitu pada uji motility, voges proskaeur, produksi indol, produksi $\mathrm{H}_{2} \mathrm{~S}$, uji gula-gula sucrose dan glycerol. $A$. hydrophila memiliki sifat motil, voges proskaeur positif, produksi indol positif, memproduksi $\mathrm{H}_{2} \mathrm{~S}$, sucrose positif dan glycerol positif, sedangkan $A$. salmonicida memiliki sifat non motil, voges proskaeur negatif, produksi indol negatif, produksi $\mathrm{H}_{2} \mathrm{~S}$ negatif, sucrose dan glycerol negatif.
Patogenisitas Aeromonas spp.

Uji patogenisitas dilakukan terhadap isolat GKJ1, GKJ4, GGN2, GGN5, GPR2 dan GPR4. Isolat tersebut diseleksi berdasarkan perbedaan lokasi pengambilan sampel dan jenis bakteri. Bakteri yang dipilih adalah $A$. hydrophila. Hasil uji patogenesitas dilihat pada Tabel 2.

Nilai LD $_{50}$ isolat $A$. hydrophila GKJ1 sebesar $1,55.10^{5}$ cfu/ikan dan isolat $A$. hydrophila GKJ4 sebesar $3,89 \cdot 10^{5} \mathrm{cfu} /$ ikan. Nilai LD $_{50}$ isolat $A$. hydrophila GGN2 sebesar $7,24.10^{5} \mathrm{cfu} / \mathrm{ikan}$ dan isolat $A$. hydrophila GGN5 sebesar $2,39.10^{4} \mathrm{cfu} / \mathrm{ikan}$. Nilai LD $_{50}$ isolat A. hydrophila GPR2 sebesar $6,61.10^{4}$ cfu/ikan dan isolat $A$. hydrophila GPR4 sebesar $1,95.10^{5}$ cfu/ikan. Semua isolat yang diuji memiliki tingkat keganasan yang bersifat virulen sesuai dengan acuan (Nitimulyo, 1993).

Keganasan bakteri dalam penelitian ini lebih rendah dibandingkan dengan hasil penelitian Supriyadi \& Shariff (1996) dan Triyanto (1990). Triyanto (1990) menyatakan nilai $\mathrm{LD}_{50} A$. hydrophila isolat Cisaat: 3,98 x $10^{4} \mathrm{cfu} / \mathrm{ikan}$, isolat Cimanggis: $5,47 \times 10^{4} \mathrm{cfu} / \mathrm{ikan}$, dan isolat Yogyakarta: $8,99 \times 10^{4} \mathrm{cfu} / \mathrm{ikan}$. Supriyadi \& Shariff (1996) menyatakan nilai LD ${ }_{50}$ A. hydrophila yang diinfeksikan secara suntikan intraperitoneal adalah $6,70 \times 10^{4} \mathrm{cfu} / \mathrm{ikan}$ pada lele dumbo.

Vaksinasi merupakan salah satu cara pencegahan terhadap penyakit ikan dengan merangsang kekebalan ikan terhadap penyakit tertentu. Vaksinasi tidak memiliki dampak negatif baik pada ikan, lingkungan maupun konsumen. Dengan demikian, penggunaan vaksin tampaknya memiliki harapan yang cukup naik. Faktor yang mempengaruhi keberhasilan vaksinasi faktor pemeliharaan dan sifat vaksin. Faktor pemeliharaan yang berpengaruh adalah kesehatan ikan, pakan ikan, adanya polutan, antibiotik dan pengaruh lingkungan. Sedangkan sifat vaksin yang berpengaruh adalah jenis antigen, dosis antigen dan cara vaksinasi (Ellis, 1988). Hasil penelitian ini menunjukkan adanya perbedaan karakteristik biokimia dan juga patogenisitas antar isolat. Adanya

Tabel 2 Tingkat keganasan Aeromonas hydrophila yang diinfeksikan pada lele dumbo.

\begin{tabular}{ccc}
\hline Isolat & LD $_{50}(\mathrm{cfu} / \mathrm{ml})$ & Tingkat keganasan \\
\hline GKJ1 & $1,55.10^{6}$ & Virulen* $^{*}$ \\
GKJ4 & $3,89.10^{6}$ & Virulen* $^{*}$ \\
GGN2 & $7,24.10^{6}$ & Virulen* \\
GGN5 & $2,39.10^{6}$ & Virulen* $^{*}$ \\
GPR2 & $6,61.10^{5}$ & Virulen* $^{*}$ \\
GPR4 & $1,95.10^{5}$ & Virulen* $^{*}$ \\
\hline
\end{tabular}

Keterangan : * $=10^{4}-10^{6} \mathrm{cfu} / \mathrm{ml}$ ( Nitimulyo et al., 1993). 
keragaman keganasan menunjukkan adanya keragaman sifat antigensitasnya. Pengembangan vaksin dalam bentuk polivalen atau vaksin dari strain yang mempunyai sifat common antigen merupakan strategi pengembangan vaskin yang disarankan (Stevenson, 1988).

\section{Kesimpulan}

Sejumlah 15 isolat bakteri Aeromonas sp. penyebab penyakit telah berhasil diisolasi dari ginjal lele dumbo dari Kabupaten Ngawi yang terdiri atas dua belas isolat $A$. hydrophila dan tiga isolat $A$. salmonicida. Terdapat keragaman patogensitas isolat bakteri $A$. hydrophila dan termasuk kategori virulen.

\section{Ucapan Terima Kasih}

Penelitian ini dibiayai dari Hibah Penelitian Fakultas Pertanian Universitas Gadjah Mada.

\section{DAFTAR PUSTAKA}

Angka, S.L., T.J. Lam \& Y.M. Sin. 1995. Some virulence characteristics of Aeromonas hydrophila in walking catfish. Aquacultur 130 : 103-112.

Austin, B. \& D.A. Austin. 1987. Bacteria Fish Pathology; Diseases in Farmed and Wild Fish. Ellis Horwood Limited, England.

Ellis, A.E. 1988. Optimizing Factors for Fish Vaccination. In: fish vaccination. A.E. Ellis. (Ed). Academic Press, London : 32-46.

Holt, J.G., N.R. Krieg, P.H.A. Sneath, J.T. Staley \& S.T. Williams. 1994. Bergey's Manual of Determinative Bacteriology. $9^{\text {th }}$ ed. William \& Wilkins. Departement of Microbiology, Gltner Hall, Michigan State University, East lansing, MI, USA, 48824-1101.

Hubert, J.J. 1980. Biossay. Kendall/Hunt Publishing Company, Lowa, USA

Irianto, A., 2004. Patologi Ikan Teleostei. Gadjah Mada Univesity Press, Yogyakarta.
Nitimulyo, K.H., A. Sarono., I.Y.B. Lelana., N. Widodo., E.B. Thaib., S. Haryani., Haryanto., Triyanto., Ustadi., A.N. Kusumahati., W. Novianti., S. Wardani \& Setianingsih. 1993. Hama dan Penyakit Ikan Golongan Bakteri : Buku 2. Pusat Karantina Pertanian dan Jurusan Perikanan. Fakultas Pertanian. Universitas Gadjah Mada.

Nitimulyo, K.H. 1996. Vibriosis pada ikan dan alternatif penanggulangannya. Jurnal Perikanan I (I) : 78-86.

Macfaddin, J.F. 1980. Biochemical Test for Identification of Medical Bacteria. $2^{\text {nd }}$ ed. Williams \& Wilkins, Waverly Press, Inc. Mt. Royal, and Guilferd Aves, Baltimore Md. 21202, USA

Murwantoko, Rozi, I. Istiqomah \& K.H. Nitimulyo. 2013. Isolasi, Karakterisasi dan Patogenitas Bakteri Penyebab Penyakit pada Gurami (Osphronemus goramy) di Kabupaten Bantul. Jurnal Perikanan 15:83-90

Noga, E.J. 2000. Fish Disease Diagnosis and Treatment. lowa State Press, North California.

Stevenson, R.M.W. 1988. Vaccination againt Aeromonas hydrophila. In: fish vaccination. A.E. Ellis. (Ed). Academic Press, London : 112-123.

Supriyadi, H \& M. Shariff. 1996. Determinasi virulensi beberapa isolat Aeromonas hydrophila dengan metode Plate Assay dan $L_{50}$. Prosiding Simposium Perikanan Indonesia I. Badan Penelitian dan Pengembangan Pertanian. Jakarta : 279-284.

Triyanto. 1990. Patogenesitas beberapa isolat Aeromonas hydrophila terhadap ikan lele (Clarias Batracus L). Prosiding Seminar Nasional II Penyakit Ikan dan Udang 16-18 Januari. Badan Peneliti dan Pengembangan Pertanian : 116-121.

Wakabongo, M., B. Enoch., B. F.A. Meier \& H.P. Dalton. 1992. Rapid identification of motil Aeromonas. Diagn Microbiology Infect Dis 15 : 511-515. 